\title{
Effect of large and small herbivores on seed and seedling survival of Beilschmiedia miersii in central Chile
}

\author{
Efecto de herbívoros mamíferos pequeños y grandes sobre la sobrevivencia \\ de semillas y plántulas en la restauración de Beilschmiedia miersii en Chile central
}

\author{
Narkis S Morales ${ }^{\mathrm{a}, \mathrm{b}^{*},}$ Pablo I Becerra ${ }^{\mathrm{c}, \mathrm{d}}$, Eduardo C Arellano ${ }^{\mathrm{c}, \mathrm{d}}$ and Horacio B Gilabert ${ }^{\mathrm{c}}$ \\ *Corresponding author: ${ }^{a}$ Macquarie University, Faculty of Science and Engineering, Department of Biological Sciences, \\ Building E8A Room 281, NSW 2109, Sydney, Australia, tel.: +61 45 7333053, narkis.moralessanmartin@mq.edu.au \\ ${ }^{\mathrm{b}}$ Fundación para la Conservación y Manejo Sustentable de la Biodiversidad, Ahumada 312, oficina 425, \\ Santiago Centro, Santiago, Chile, tel.: +56 22426996. \\ c Pontificia Universidad Católica de Chile, Facultad de Agronomía e Ingeniería Forestal, Departamento de Ecosistemas y Medio \\ Ambiente, Av. Vicuña Mackenna 4860, Santiago, Chile, tel.: +56 2 3544169, fax: +56 23545982. \\ ${ }^{d}$ Center of Applied Ecology and Sustainability (CAPES), Av Libertador Bernardo O’higgins 340, Santiago Chile.
}

\section{SUMMARY}

In the Mediterranean region of Chile, populations of the threatened tree Beilschmiedia miersii have been strongly affected by anthropic disturbances, causing a critical state of conservation. Herbivory has been proposed as the main factor that currently limits the regeneration of this species. We studied the effect of large vs. small herbivores on seed and seedling survival of $B$. miersii under two contrasting habitat conditions (forest and shrubland), using plots with fenced enclosures which differentially excluded mammalian herbivores according to body size. Results show that herbivory had a significant negative effect on B. miersii. Both large and small herbivores had a significant negative effect on seeds and seedlings in the shrub habitat. In the forest habitat small herbivores had a significant negative effect only on seeds. Our results suggest that different herbivores can have varying effects on seed and seedling survival, but these effects can vary spatially, probably due to different herbivore assemblage of each habitat. Results suggest that restoration plans for $B$. miersii need to be adjusted according to local conditions.

Key words: Beilschmiedia miersii, herbivory, seed predation, seedling survival, restoration.

\section{RESUMEN}

En la zona mediterránea de Chile, las poblaciones de la especie amenazada Beilschmiedia miersii han sido afectadas fuertemente por actividades antrópicas, provocando que actualmente se encuentre en un estado crítico de conservación. La herbivoría ha sido propuesta como el principal factor que limita actualmente la regeneración de esta especie. El efecto de herbívoros grandes versus pequeños, la etapa del ciclo de vida más afectada (semillas vs. plántulas) y si la sobrevivencia depende de las condiciones de hábitat permanece menos conocida. En este estudio evaluamos el efecto de diferentes tipos de herbívoros en la sobrevivencia de semillas y plántulas de $B$. miersii usando parcelas con cierres perimetrales que excluyeron a los herbívoros mamíferos de acuerdo a su tamaño. También evaluamos la variabilidad espacial del efecto de los herbívoros comparando entre habitas de matorral y bosque. Los resultados muestran que la herbivoría tuvo un efecto significativamente negativo sobre B. miersii. Ambos herbívoros, grandes y pequeños, tuvieron un efecto significativamente negativo sobre semillas y plántulas en el hábitat de matorral, donde la sobrevivencia de plántulas fue de 2,5\% para exclusiones parciales y cero para parcelas sin exclusión. La sobrevivencia de semillas fue nula en las exclusiones parciales y en parcelas sin exclusión. En el hábitat de bosque los herbívoros pequeños tuvieron un efecto negativo solo sobre semillas. La sobrevivencia de semillas fue nula en parcelas parcialmente excluidas y parcelas sin exclusión. Nuestros resultados indican que diferentes tipos de herbívoros pueden tener efectos variados sobre semillas y plántulas, pero estos resultados pueden variar espacialmente, debido probablemente a los diferentes ensamblajes de herbívoros en cada hábitat. Los resultados sugieren que los planes de restauración de B. miersii deben ser ajustados de acuerdo al hábitat y al tipo de herbívoro.

Palabras clave: Beilschmiedia miersii, herbivoría, depredación de semillas, sobrevivencia de plántulas, restauración.

\section{INTRODUCTION}

In the last few decades restoration plans have become crucial to preserve threatened species and degraded ecosys- tems (Hobbs and Harris 2001). The success of conservation and restoration actions in plant species depends on factors that restrict regeneration (Sweeney and Czapka 2004). Herbivory has been observed to be an important limiting factor 
for natural regeneration, plantations and restoration (Holmgren 2002, Gutiérrez et al. 2007).

Because of herbivory, most conservation and restoration programs should include exclusion or vertebrate herbivore control, incurring in high costs (Sweeney and Czapka 2004). However, in many plant species different types of herbivores can have diverse impact levels and affect different life-cycle stages (seed vs. seedling) (e.g. Simonetti and Fuentes 1983, Henríquez and Simonetti 2001, Gutiérrez et al. 2007). Therefore, knowledge of the most important herbivore types (e.g. large vs. small mammals), the life-cycle stage that is most affected and the required control techniques can be crucial to the viability and location of restoration activities.

The vegetation of the Mediterranean zone of Central Chile $\left(27^{\circ}-38^{\circ} \mathrm{S}\right)$ has been altered due to prolonged anthropogenic activities such as fires, agriculture, populated centers, mining activities, and introduction of wild and domestic exotic species (Novoa 2004). Although there is some evidence of herbivory from native mammals (Simonetti and Fuentes 1983), introduced mammals such as cows, goats, the European rabbit, and rodents have been considered as the most important herbivores limiting the recruitment of woody species in central Chile (Simonetti and Fuentes 1983, Gutiérrez et al. 1997, 2007, Henríquez and Simonetti 2001, Holmgren 2002, Becerra and Bustamante 2008). Therefore, herbivory by exotic mammals can be a major constraint on the conservation and restoration of Chilean native plant species.

Beilschmiedia miersii (Gay) Kosterm is an endemic and endangered (Benoit 1989) evergreen tree species that is dis- tributed in coastal forests in central Chile from $32^{\circ} 33^{\prime}$ to $34^{\circ} 02^{\prime} \mathrm{S}$ (Marticorena and Rodríguez 2001). It is a higrophyllous species (Becerra et al. 2004), found along humid and shaded environments (Novoa 2004). It is a shade-tolerant plant, averaging $25 \mathrm{~m}$ high; its fruits are drupes $(4 \mathrm{~cm}$ long, 2-3 cm wide), the largest fruits for the Mediterranean trees species of Central Chile (Marticorena and Rodríguez 2001), and currently, no dispersal agent is known (Henríquez and Simonetti 2001). Although logging and habitat replacement were the main drivers of its population reduction (Novoa 2004), herbivory by exotic mammals has been proposed as the main factor currently limiting the regeneration of this species (Henríquez and Simonetti 2001). These authors reported significant seed and seedling predation on this species within a forest habitat (within and outside a national park in central Chile), and observed that different exotic mammals, especially goats, are potential main predators. To increase the knowledge of the effects of herbivory on regeneration of this species, new similar studies are necessary in other localities and environmental conditions. In this study we explored the effect of different types of herbivores on survival of seeds and seedlings of $B$. miersii in two sites with different vegetation structure in a semicoastal locality of central Chile. Our results may be useful to increase the efficiency of restoration plans in the area.

\section{METHODS}

Study site. The study area was located in the Nogales commune, Valparaiso Region, approximately $132 \mathrm{~km}$ North of Santiago (32०39'20' S, $\left.71^{\circ} 09^{\prime} 18^{\prime \prime} \mathrm{W}\right)$ (figure 1). The
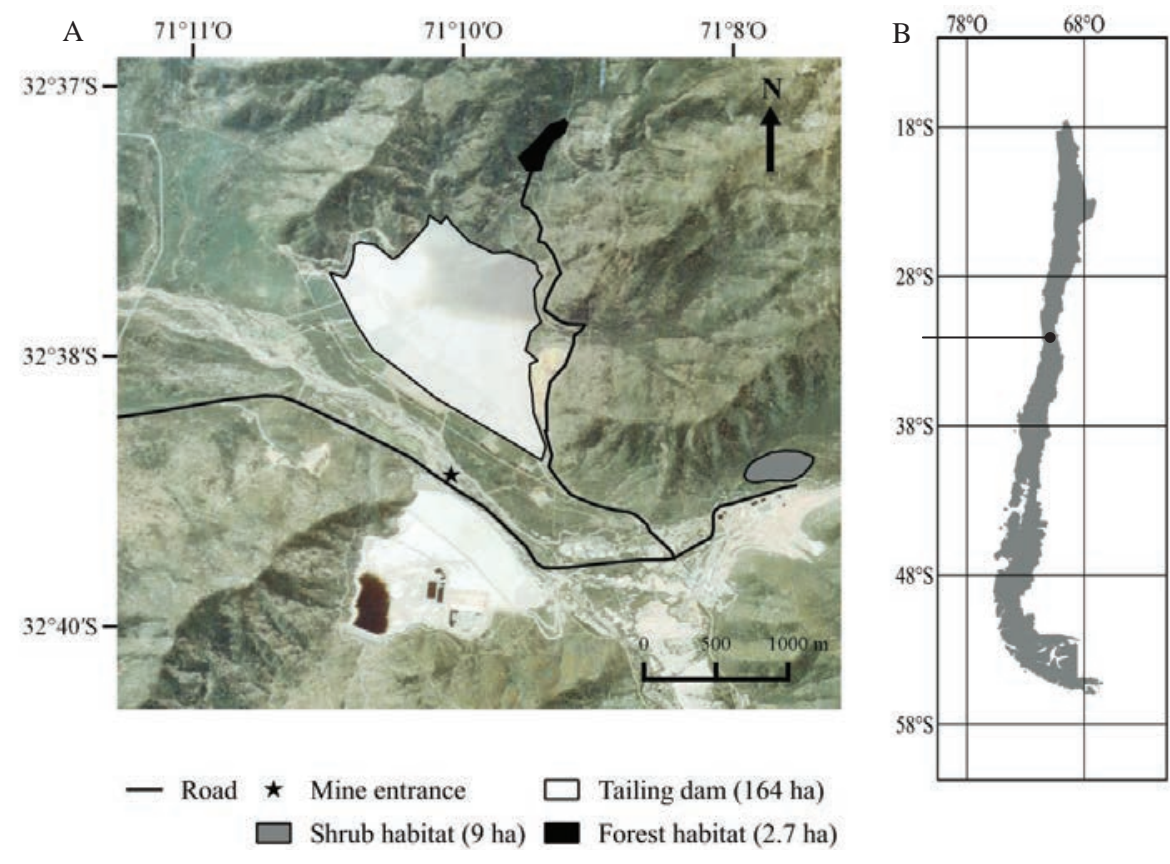

Figure 1. Map of the study area showing the regional location within Chile (B) and the study site showing the two habitat types (A).

Mapa del área de estudio que muestra la ubicación regional en Chile (b) y el sitio de estudio incluyendo los dos tipos de hábitats (a). 
zone presents a Mediterranean climate, with certain oceanic influences, an average temperature of $14.4{ }^{\circ} \mathrm{C}$, annual precipitation of $424.2 \mathrm{~mm}$ and annual average humidity of $80 \%$ according to the nearest climate station data in Quillota (32 ${ }^{\circ} 53^{\prime} \mathrm{S}, 71^{\circ} 16^{\prime} \mathrm{W}, 128 \mathrm{~m}$ a.s.l.) (Di Castri and Hajek 1976). The study area presents sclerophyllous forests, dominated by Cryptocarya alba (Mol.) Looser, Citronella mucronata (R. et P.) D. Don., and Crinodendron patagua Mol. Currently, the main activity in the area is copper mining, although cattle grazing from neighboring farms is frequent.

Treatments and experimental design. We chose two sites, $3 \mathrm{~km}$ apart, to repeat the experiment; each presenting similar physical environmental conditions: hygrophyllous habitats corresponding to south-facing slopes bordering a river, but with different levels of human disturbance. One site presented a "shrub habitat" which was probably more recently disturbed by logging ( $32^{\circ} 39^{\prime} 08^{\prime \prime} \mathrm{S}, 71^{\circ} 08^{\prime} 29^{\prime}$ " W). The other sites presented a "forest habitat" corresponding to a secondary forest with no recent evidence of logging (at least 30 years) ( $32^{\circ} 37^{\prime} 37^{\prime}$ S, $71^{\circ} 09^{\prime} 20^{\prime}$ W). Both habitats are representative of two typical vegetation conditions found in central Chile which need ecological restoration (Fernández et al. 2010).

We used three treatments to assess the effect of different types of mammalian herbivores on seeds and seedlings: a) total exclusions: 3 x 3 m plot fenced on all sides, made of wire mesh with $1.3 \mathrm{~cm}$ diameter holes, b) partial exclusions: $3 \times 3$ m plot fenced using four wooden posts with three barbed wire lines in order to exclude large herbivores $(>30 \mathrm{~cm}$ in height) but allowing access to small herbivores $(<30 \mathrm{~cm}$ in height), c) unfenced plots: a 3 x 3 m unprotected plot with free access for all types of vertebrate herbivores.

Unfenced plots allowed us to assess the effect of all mammalian herbivores on seeds and seedlings. The contrast between partial exclusions and unfenced plots allowed us to assess the effect of large herbivores, while the contrast between partial exclusions and total exclusions allowed us to detect the effect of small herbivores since the effect of large herbivores is prevented in both cases. Insect herbivory is not evaluated in this study and is assumed to be homogeneous among treatments.

In each habitat we used four replicates, each of which included one plot of each of the three treatments no more than $3 \mathrm{~m}$ apart to guarantee that seeds and seedlings among the three plots were located on the same soil type, vegetation cover and assemblage of herbivores. The four replicates of these three treatment groups were located at least 50 $\mathrm{m}$ apart in each site. This distance probably does not ensure independence among replicates as many animals may move more than $50 \mathrm{~m}$. However, this distance allowed us to increase, to some extent, the probability that replicates were visited by different individuals of each species of herbivore.

Seedlings and seeds were obtained from the same populations of $B$. miersii located in the study area. In each $3 \mathrm{x}$
3 m plot, we placed 20 seeds and 10 seedlings, which were planted approximately $30 \mathrm{~cm}$ apart. Seedlings were eight months old at time of planting, and plant height was $37 \mathrm{~cm}$ \pm 5.28 (mean $\pm 1 \mathrm{SD}$ ). Sowing and planting were carried out in September, 2007. Seedling and seed survival were assessed in three periods 45 days apart, between September 2007 and March 2008. In each survey every seedling was assigned to one of these categories: "surviving” which included plants without damage and no or few indications of drying, as well as alive plants with damage by cutting, with at least one green leaf; "predated" which included plants with severe damage of herbivory, without presence of green leaves and with a remaining stem, as well as absent plants (no presence in its original place of plantation, frequently with soil disturbance). Other plants were denominated "dried" which included plants with brown and fragile leaves and stems with no evidence of cutting. Regarding seeds, in each survey, the number of seeds in each plot was counted, and absent seeds were assumed to have been eaten.

This design allowed us to find only some preliminary evidence about the role of herbivory on seed and seedling survival and establishment. Thus, we were able to detect some effect of herbivory in two different sites with different vegetation structure but not to evaluate interactions between habitat conditions and herbivory.

Herbivore composition. We sampled the rodent composition in both habitats using Sherman ${ }^{\circledR}$ traps and oat as bait. We used a total of 24 traps, 12 traps per habitat, on four consecutive nights. The traps were checked every morning and they were set up for the next day in the afternoon. Sampling was conducted once at the beginning of the experiment in September 2007. In addition, 241 x $1 \mathrm{~m}$ quadrants (12 in each habitat) were marked with a stake at each vertex to assess the abundance of the European rabbit (Oryctolagus cuniculus Linnaeus, 1758) through the faecal deposition rate. At the start of the experiment we removed all faeces present in each quadrant. Then, in each visit the number of $O$. cuniculus faeces was counted (from October 2007 to March 2008). This method allowed us to assess the deposition rate each 45 days, which is a time short enough to count all newly deposited faeces before they completely decay (Simonetti 1989) and thus to assess and compare, indirectly, abundance of rabbits between habitats. We also conducted cow (Bos Taurus Linnaeus, 1758) and horse (Equus caballus Linnaeus, 1758) faecal counts, in four randomly distributed $5 \times 5 \mathrm{~m}$ plots in each habitat. We did not observe feces of other herbivores (sheep, goats). This survey was carried out once in March of 2008.

Data and statistical analyses. To determine if there were differences in the number of faeces of $O$. cuniculus, or number of faeces of $B$. taurus and $E$. caballus (pooled) we used one way ANOVA separately for each variable and habitat. 
A Kruskal-Wallis rank sum test was used to assess the effect among the different treatments (total exclusion, partial exclusion, unfenced plots) on the survivorship of seedlings (surviving plants) and seeds with a post-hoc test using Mann-Whitney tests with Bonferroni correction. These analyses were carried out using the four plots of each herbivory treatment per habitat as replicates. To avoid pseudo-replication, we used the survival percentage of ten seedlings and twenty seeds in each plot as a replicate.

In addition, we evaluated the percentage of seedling mortality specifically due to herbivory using all the seedlings in the partial exclusion and unfenced plots in category "predated". In the forest habitat, one of the total exclusion treatments had a hole where it is presumed a small herbivore entered and consumed only the seeds, not seedlings. As a consequence, we eliminated this plot from the statistical analyses for seeds.

Analyses were carried out using the packages "stats" (R Core Team 2012), in R-2.15.1 (R Core Team 2012). In all statistical analyses we used a significant $P$ value of 0.05 . No comparisons between habitats were made because of lack of habitat replication.

\section{RESULTS}

Herbivore composition. In the shrub habitat, three rodents species were captured (September 2009): the common mouse (Mus musculus Linnaeus) $(\mathrm{n}=3$ ), black rat (Rattus rattus Linnaeus) $(\mathrm{n}=16)$ and the native rodent degu (Octodon degus Molina) $(\mathrm{n}=2)$. In the forest habitat, only one individual of $R$. rattus was captured, as well as one chinchilla mouse (Abrocoma bennetti Waterhouse). Therefore, abundance of rodents, particularly $R$. rattus, was also higher in the shrub than in the forest habitat and O. degus was only observed in the shrub.

There were significant differences in the number of O. cuniculus faeces between habitats $(\mathrm{F}=19.790 ; P<0.001)$. The number of faeces of $O$. cuniculus in the shrub habitat was $67.3 \pm 7.8$ (mean $\pm 1 \mathrm{SE}$ ) faeces per quadrant, while in the forest habitat there only were $2.2 \pm 1.2$ (mean \pm 1 SE) faeces per quadrant. The number of faeces of B. taurus and E. caballus did not significantly differ between habitats $(\mathrm{F}=3.334$; $P=0.098$ ). The number of $B$. taurus and $E$. caballus faeces was $4 \pm 2.3$ (mean $\pm 1 \mathrm{SE}$ ) in the shrub habitat and in the forest there were $7 \pm 18.3$ (mean $\pm 1 \mathrm{SE}$ ) faeces per quadrant.

Herbivory effects on seedling survival. In the shrub habitat, during the first survey ( 45 days after planting), seedling herbivory was $92.5 \%$ and $95 \%$ in partial exclusion and unfenced plots, respectively. In the following assessment period seedling herbivory reached $100 \%$ in both treatments. There was no evidence of herbivory on seedlings in the total exclusions. In the forest habitat, seedling herbivory in partial exclusion and unfenced plots were only $15 \%$ and $30 \%$, respectively at the end of the experiment, and also no seedlings were predated in total exclusions.
At the end of the experiment, the percentage of seedling survival in the shrub habitat was $20 \%$ and $2.5 \%$ for total exclusion and partial exclusion, respectively, and unfenced plots did not show any surviving seedlings (figure 2). The survival percentage obtained at the end of the experiment for total exclusion, partial exclusion and unfenced plots were of $37.5 \%, 27.5 \%$ and $45 \%$, respectively (figure 2).

In the shrub habitat there were significant differences among herbivory treatments $\left(\mathrm{Chi}^{2}=11\right.$; d.f $\left.=2 ; P<0.01\right)$. Seedling survival in the total exclusion was significantly higher than in the partial exclusion $(P<0.05 ; r=0.76)$ and unfenced plots $(P<0.05 ; r=0.76)$. There were no significant differences between the partial exclusion and unfenced plots. In the forest habitat there were no significant differences among herbivory treatments $\left(\mathrm{Chi}^{2}=4.82\right.$; d.f $=2 ; P=0.08)$.

Herbivory effects on seed survival. Forty-five days after the beginning of the experiment, seed survival was null in all the partial exclusion and unfenced plots in the shrub habitat while survival in the forest habitats was quite higher (figure 3). In turn, at the end of the experiment survival was null in all the partial exclusions and unfenced plots in both habitats (figure 3 ).

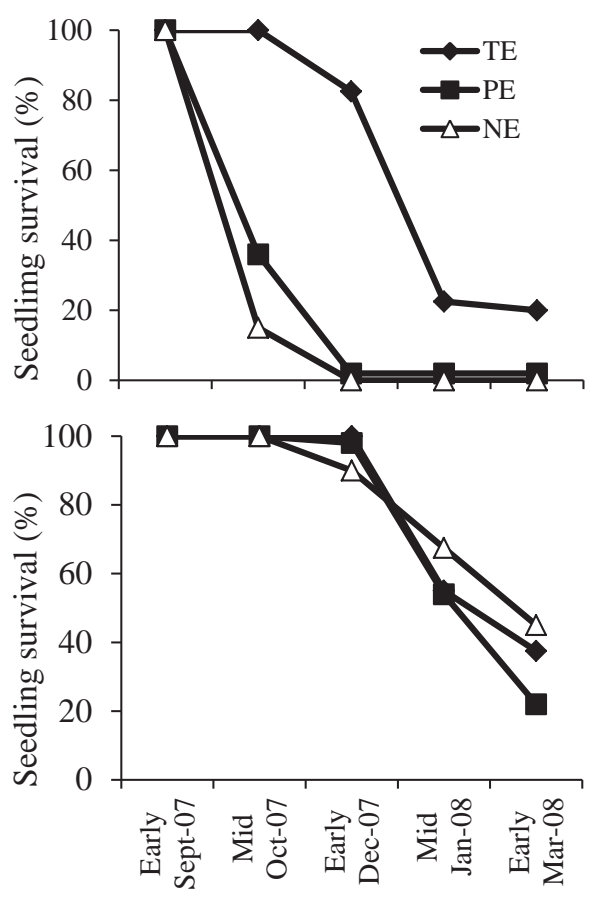

Figure 2. Seedling survival curves in the shrub and forest habitats ( $n=4$ per herbivory treatment and habitat). Herbivory treatments: TE: total exclusion; PE: partial exclusion; NE: unfenced plot.

Curvas de sobrevivencia de plántulas en hábitat de matorral y bosque ( $\mathrm{n}=4$ plántulas por tratamiento de herbivoría y hábitat). Tratamientos de herbivoría: TE: exclusión total; PE: exclusión parcial; NE: sin exclusión. 


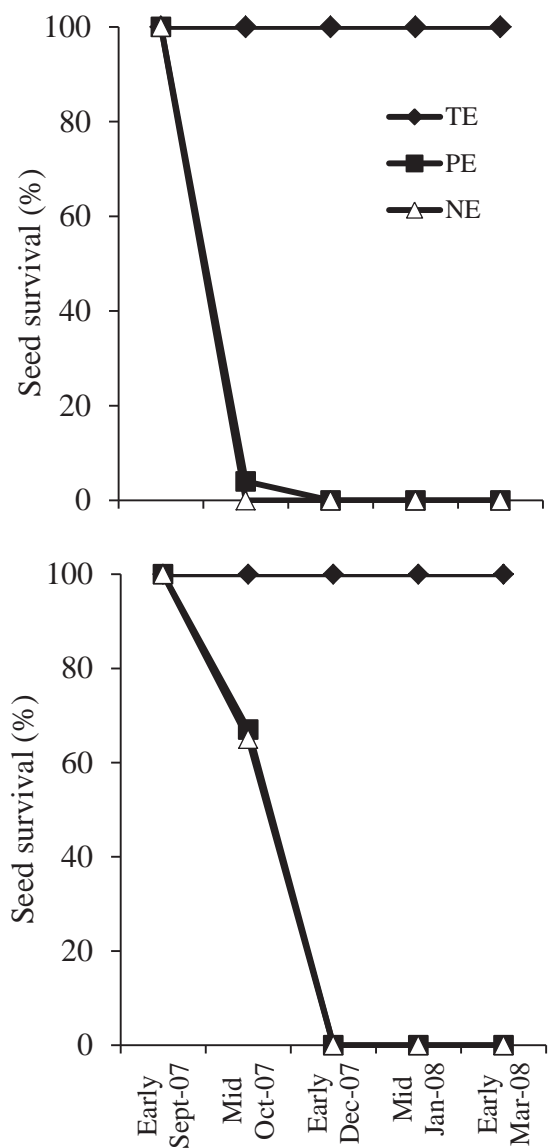

Figure 3. Seed survival curves in the shrub and forest habitats ( $n=4$ per herbivory treatment and habitat). Herbivory treatments: TE: total exclusion; PE: partial exclusion; NE: unfenced plots.

Curvas de sobrevivencia en hábitat de matorral y bosque ( $\mathrm{n}=4$ semillas por tratamiento de herbivoría y hábitat). Tratamientos de herbivoría: TE: exclusión total; PE: exclusión parcial; NE: sin exclusión.

In the shrub habitat there were significant differences in the survival of seeds among herbivory treatments $\left(\mathrm{Chi}^{2}\right.$ $=11$; d.f $=2 ; P<0.01)$. The survival of seeds in the total exclusions was significantly more important than in the partial exclusions $(P<0.05 ; r=0.76)$ and unfenced plots $(P<0.05 ; r=0.76)$. There were no significant differences between the partial exclusion and unfenced plots.

In the forest habitat there were significant differences in seed survival among herbivory treatments $\left(\mathrm{Chi}^{2}=10\right.$; d.f $=2 ; P<0.01)$. Survival was significantly higher in the total exclusion plots than in partial exclusions $(P<0.05$; $r=0.70)$ and unfenced plots $(P<0.05 ; r=0.70)$, with no differences between the last two treatments.

\section{DISCUSSION}

Our results suggest that in this locality, herbivory can have an important negative effect on the survival of seedlings and seeds of $B$. miersii, and that the importance of this effect may depend on factors such as type of herbivore (large vs. small), life-cycle stage (seed vs. seedling) and local conditions of habitats. Despite the small sample used in the study, the results presented here provide valuable information for future restoration and conservation plans of this endemic and endangered species.

From all the small herbivores observed in our study areas $O$. cuniculus poses the largest threat to seedlings. Oryctolagus cuniculus has been identified as the main seedling herbivore in Chile and in other parts of the world (Simonetti and Fuentes 1983, Holmgren 2002, Gutiérrez et al. 2007, Becerra and Bustamante 2008), though it does not necessarily destroy them completely (Simonetti and Fuentes 1983, Gutiérrez et al. 1997). Instead, seeds are mostly under threat from the black rat ( $R$. rattus) (Wara et al. 2006), which rarely eat seedlings. O. cuniculus does not eat large seeds like those from $B$. miersii, and therefore their influence on the survival of seeds can be ruled out (Simonetti and Fuentes 1983). This is also the case of the common mouse (M. musculus) which is mainly a predator of small seeds (Jaksic 1998).

From the large vertebrates identified, B. taurus probably represents a larger threat to $B$. miersii as it could feed on both seedlings and seeds, whereas E. caballus would only feed on seedlings (Henríquez and Simnonetti 2001). Spalacopus cyanus is mainly a root and bulb predator; hence they can be ruled out as herbivore of B. miersii and thus not considered a challenge to the establishment or recruitment of this particular species (Contreras and Gutiérrez 1991). Therefore, among small and large mammals, rats and cows respectively may be the main predators of seeds of $B$. miersii, while seedlings may be predated by rabbits (small herbivore) as well as cows and horses (large herbivores).

The defecation rate of $O$. cuniculus suggests that rabbits are considerably more abundant in the shrub habitat than in the forest. The higher abundance of $O$. cuniculus in the shrub habitat would allow us to explain the negative effect on seedling survival and the absence of that effect in the forest habitat. These patterns are similar to other studies documenting low importance of $O$. cuniculus and small mammals on seedling survival of this species in forest habitats (Simonetti 1989, Henríquez and Simonetti 2001, Becerra and Bustamante 2008). This was similar to what was observed with large herbivores, which did not have a significant effect on seedling or seed survival in the forest habitat. These results are contradictory to results found in other studies about this species such as Henríquez and Simonetti (2001), who suggested that large herbivores would be the main consumers of seedlings and seeds of $B$. miersii within forest habitats. Nevertheless, Henríquez and Simonetti (2001) observed that large herbivores represented the majority of herbivores and were probably more abundant, particularly goats, than small herbivores. Instead, goats were not observed in our study. In our study it is likely that large herbivores do not use the forest habitat to feed, but only to rest and get protection against bad weather conditions. 
Despite this fact, large herbivores could still pose a threat to seedlings by trampling them. Further studies should assess the impact of this activity on seedling survival.

The differences observed between sites with different vegetation structure in our study, together with the different results observed by Henríquez and Simonetti (2001) allow us to predict that the effect of the type of herbivore of $B$. miersii can vary spatially, for instance, due to dissimilar herbivore assemblages present in different sites or habitats. This is supported by Sweeney and Czapka (2004) who state that each site needs its own ecological prescription for restoration. For instance, if restoration in our study area was to be carried out by planting seedlings, protection against both small and large herbivores should be installed only in the shrub habitat. If restoration is carried out by sowing seeds, protection against both small and large herbivores would be needed in the shrub habitat and only against small mammals in the forest habitat. Since in the forest habitat only small mammals need to be considered, an eradication program could be more appropriate instead of fencing.

Our results suggest that the main herbivores on $B$. miersii in this area (O. cuniculus, $R$. rattus, B. taurus and E. caballus) are all exotic invasive mammals, similar to what Henríquez and Simonetti (2001) found in another locality in central Chile. These findings show how important it is to control exotic herbivore invasions in order to achieve the long-term conservation of threatened species and/or subsequent successful restoration processes (Gutiérrez et al. 2007). Nevertheless, our results suggest that, contrary to common practice, it is not always necessary to exclude all herbivores to obtain good restoration results.

\section{ACKNOWLEDGMENTS}

The authors thank Anglo American Chile for financing the experiment in the field. We also want to thank I. Fernández, Professor G. Montenegro and G. Muschett for their support.

\section{REFERENCES}

Becerra P, JL Celis-Diez and RO Bustamante. 2004. Effect of leaf litter and precipitation on germination and seedling survival of the endangered tree Beilschmiedia miersii (Gay) Kosterm. Applied Vegetation Science 7: 253-257.

Becerra PI, RO Bustamante. 2008. The effect of herbivory on seedling survival of the invasive exotic species Pinus radiata and Eucalyptus globulus in a Mediterranean ecosystem of Central Chile. Forest Ecology and Management 256: 1573-1578.
Benoit I. 1989. Libro rojo de la flora terrestre de Chile. Ministerio de Agricultura. Santiago, Chile. Corporación Nacional Forestal. $157 \mathrm{p}$.

Contreras LC, JR Gutiérrez. 1991. Effects of the subterranean herbivorous rodent Spalacopus cyanus on herbaceous vegetation in arid coastal Chile. Oecologia 87: 106-109.

Di Castri F, ER Hajek. 1976. Bioclimatología de Chile. Santiago, Chile. Imprenta Editorial de la Universidad Católica de Chile. 129 p.

Fernández I, N Morales, L Olivares, J Salvatierra, M Gómez, G Montenegro. 2010. Restauración ecológica para ecosistemas nativos afectados por incendios forestales. Gráfica LOM, Santiago, Chile. 162 pp.

Gutiérrez JR, M Holmgren, R Manrique, FA Squeo. 2007. Reduced herbivore pressure under rainy ENSO conditions could facilitate dryland reforestation. Journal of Arid Environments 68: 322-330.

Gutiérrez JR, PL Meserve, S Herrera, LC Contreras, FM Jaksic. 1997. Effects of small mammals and vertebrate predators on vegetation in the Chilean semiarid zone. Oecologia 109: 398-406.

Henríquez CA, JA Simonetti. 2001. The effect of introduced herbivores upon an endangered tree (Beilschmiedia miersii, Lauraceae). Biological Conservation 98: 69-76.

Hobbs RJ, JA Harris. 2001. Restoration Ecology: Repairing the Earth's Ecosystems in the New Millennium. Restoration Ecology 9: 239-246.

Holmgren M. 2002. Exotic herbivores as drivers of plant invasion and switch to ecosystem alternative states. Biological Invasions 4: 25-33.

Jaksic F. 1998. Vertebrate invaders and their ecological impacts in Chile. Biodiversity and Conservation 7: 1427-1445.

Marticorena C, R Rodríguez. 2001. Flora de Chile, Vol. 2. Concepción, Chile. Universidad de Concepción. 128 p.

Novoa P. 2004. Determinación del grado de amenaza del belloto del norte (Beilschmiedia miersii Kosterm, Lauraceae), mediante el uso de la metodología UICN 2001. Chloris Chilensis 7.

R Core Team. 2012. R: A language and environment for statistical computing. R Foundation for Statistical Computing, Vienna, Austria. ISBN 3-900051-07-0, URL http:// www.R-project.org/

Simonetti JA. 1989. Microhabitat use by Oryctolagus cuniculus in central Chile: a reassessment. Mammalia 53: 363-368.

Simonetti JA, ER Fuentes. 1983. Shrub preferences of native and introduced Chilean matorral herbivores. Oecologia 4: 269272.

Sweeney BW, SJ Czapka. 2004. Riparian forest restoration: why each site needs an ecological prescription. Forest Ecology and Management 192: 361-373.

Wara M, R Bustamante, R Vásquez. 2006. Efectos de la herbivoría, el microhábitat y el tamaño de las semillas en la sobrevivencia y crecimiento de plántulas de la palma chilena. Ambiente y Desarrollo 22: 55-62. 